\title{
The aetiology and pathogenesis of major systemic vasculitides
}

\author{
Caroline O.S. Savage and Yin C. Ng \\ Department of Medicine, Royal Postgraduate Medical School, Hammersmith Hospital, Ducane Road, London \\ W120HS, UK.
}

\section{Introduction}

Systemic vasculitis is an inflammatory disorder of blood vessels characterized by a perivascular cellular infiltrate around and fibrinoid necrosis within vessel walls. It may accompany a variety of diseases and may dominate clinical and pathological findings in polyarteritis (classical and microscopic), the Churg-Strauss syndrome, Wegener's granulomatosis, HenochSchonlein purpura, giant cell arteritis and Takayasu's disease - all 'primary' systemic vasculitides, the clinical and pathological features of which are described elsewhere (Cohen et al., 1980; Scott et al., 1982; McCluskey \& Fienberg, 1983; Savage et al., 1985; Serra et al., 1984; Churg \& Strauss, 1952; Chumbley et al., 1977; Pinching et al., 1983; Fauci et al., 1983; Counahan et al., 1977). It is also associated with other well-defined systemic disorders including systemic lupus erythematosus, rheumatoid arthritis, mixed essential cryoglobulinaemia, subacute bacterial endocarditis and various types of malignancy (Fauci $e t$ al., 1978; Cupps \& Fauci, 1982). The pathological features of these 'primary' and 'secondary' vasculitides form a spectrum in which virtually all types and sizes of blood vessels are involved and no organ system is exempt.

Immunogenetic mechanisms such as passive deposition of immune complexes, direct antibody attack and cell mediated immunity, are generally thought to underlie the systemic necrotizing vasculitides, but detailed understanding remains poor. Aetiological factors are largely unknown, as are the factors determining organ distribution, size of vessel involved, presence or absence of granulomata and clinical expression of disease.

Correspondence: C.O.S. Savage, B.Sc., M.R.C.P., Renal Unit, Royal Postgraduate Medical School, Ducane Road, London W12 0HS.

Received: 17 February 1986

\section{Immuno-pathogenetic mechanisms}

\section{Immune complexes}

\section{(a) Animal models of immune complex induced vasculitis}

The animal models of serum sickness and of the Arthus reaction have been useful in elucidating mechanisms by which antibody may react with free antigens (to produce circulating immune complexes) or with tissue-associated antigens, to mediate tissue injury. However, other good models of vasculitis which reflect more accurately the human 'primary' systemic vasculitides, particularly those associated with granuloma formation, are lacking.

Serum sickness Clark \& Kaplan (1937) first associated serum sickness with necrotizing vasculitis in man. Rich \& Gregory (1943), Germuth (1953) and Dixon et al. (1958) developed animal models in which rabbits were injected with horse serum or a large dose of a heterologous serum protein. From these studies which are well reviewed elsewhere (Cochrane \& Koffler, 1973) it became evident that circulating and tissue bound immune complexes form at the time of immune elimination and that their appearance is associated with the development of arterial, as well as glomerular, lesions. Later studies established that circulating complexes are normally removed by the reticuloendothelial system and other factors must pertain before deposition in vessel walls occurs (Cochrane \& Koffler, 1973). Such factors include vascular permeability, the size of the complexes, the affinity of the antibody, local hydrodynamic factors, the state of the reticuloendothelial system and the local characteristics of each tissue's endothelium and vessel wall architecture. Not only do multiple factors determine whether immune complexes will be deposited, but the subsequent pathogenesis of tissue injury triggered by their deposi- 
tion depends on several mediators including complement, neutrophil infiltration and possibly the coagulation and kallikrein-kinin system (Cochrane \& Koffler, 1973). Immune complexes certainly have the potential to interact with numerous humoral and cellular recognition systems since they can bind Clq, $\mathrm{C} 4 \mathrm{~b}$ and $\mathrm{C} 3 \mathrm{~b}$ complement components, fibronectin, rheumatoid factor and anti-idiotypic antibodies: these proteins can in turn interact with corresponding cell surface receptors (Nydegger, 1985). Immune complexes may also impair the function of suppressor $T$ cells and alter their expression of cell surface markers allowing the development of procoagulant activities which can initiate intravascular coagulation (Rothberger et al., 1977).

The Arthus reaction The Arthus reaction is a localized acute immune complex vasculitis which develops in the skin of sensitized animals 4-10 hours after the local injection of antigen (Cochrane, 1965). Histologically, the vessel walls show marked infiltration of red cells into the extravascular space. Early on, complexes can be identified by immunofluorescence but are removed by neutrophils within 24-48 hours of antigen injection (Cochrane et al., 1959).

The Arthus reaction follows binding of preformed antibody to antigen, with subsequent activation of complement which initiates various immune adherence reactions, release of chemotactic factors, release of anaphylatoxins ( $\mathrm{C} 3 \mathrm{a}$ and $\mathrm{C} 5 \mathrm{a}$ ) which trigger mast cell degranulation, and the formation of the membrane attack complex (Soter \& Austen, 1980). Infiltrating neutrophils bind to the complexes via their $\mathrm{C} 3 \mathrm{~b}$ receptors (CR1); phagocytosis and release of enzymes, inflammatory peptides and oxygen radicals is triggered by binding to antibody $\mathrm{Fc}$ determinants (Henson, 1982). The generation of hydrogen peroxide and the hydroxyl radical by activated neutrophils may be particularly important in mediating tissue injury (Fligiel et al., 1984); iron may potentiate injury, and catalase or iron chelators may have a protective effect.

The acute serum sickness model and the Arthus reaction suggest that immune complexes form and are then deposited, or that antibody may react with fixed tissue antigen. However, these concepts are not exclusive. Firstly, other methods of immune aggregation can be envisaged such as 'planting' of an antigen which has a particular affinity for a tissue by virtue of charge or other molecular interactions. Izui et al. (1976) reported that DNA may preferentially localize to the glomerular basement membrane. Secondly, a combination of processes may operate. Matsuo et al. (1985) demonstrated that antibody induces redistribution of surface antigen on rabbit oocytes which results in extrusion of antigen-antibody complexes into the adjacent zona pellucida where they become trapped.

\section{(b) Immune complex mediated vasculitis in man}

The evidence Vasculitis in man often develops in diseases with strong immunological associations, suggesting that the vasculitis too may be secondary to immunological damage. Evidence for immune complex mediated disease is derived from detection of circulating immune complexes using a variety of techniques, from demonstrations of their presence as cryoglobulins, from the development of hypocomplementaemia and from the demonstration of immune reactants in tissue by direct immunofluorescence. For example, circulating immune complexes (often accompanied by hypocomplementaemia) are detectable in most patients with vasculitis associated with hepatitis B infection (described in more detail below), systemic lupus erythematosus, rheumatoid arthritis, or bacterial endocarditis (Theofilopoulos \& Dixon, 1979). Cryoglobulins are associated with vasculitis in various infections, lymphoproliferative and collagen diseases (Franklin, 1980); patients with Type II mixed essential cryoglobulinaemia may also develop severe vasculitis (Gorevic et al., 1980). Immunofluorescence studies have detected complement and immunoglobulin in vessel walls, as in the dermal vessels of patients with rheumatoid arthritis (Rapoport et al., 1980), mixed essential cryoglobulinaemia (Gorevic et al., 1980) and systemic lupus erythematosus (Tan \& Kunkel, 1966). Further evidence for an association between immune complexes and vasculitis is derived from the observation that extra-articular disease in rheumatoid arthritis is associated with increased concentrations of circulating immune complexes (Zubler et al., 1976). Several investigators have found a connection between the level of immune complexes and disease activity (Scott et al., 1982) and improvement has been reported following the removal of these and other factors by plasma exchange (Lockwood et al., 1979). Further, the strong association between immune complexes, and clinical symptoms was recently demonstrated in a prospective study in which heterologous antithymocyte globulin was injected in 11 patients, 8 of whom developed serum sickness (Lawley et al., 1984).

Studies like these which have been reported by multiple centres, provide reasonable evidence that immune complexes are present in secondary vasculitides such as systemic lupus erythematosus, rheumatoid arthritis, cryoglobulinaemia and bacterial endocarditis. Yet despite their presence, it remains difficult to determine precisely the pathogenetic potential of immune complexes in systemic vasculitis since they are rarely detectable in $100 \%$ of these patients (Pussell et al., 1978), they may be present in otherwise normal tissues (Baart de la Faille-Kuyper et al., 1973) or, conversely, undetectable in tissues with typical vasculitic lesions (Conn et al., 1972), and disease activity may not correlate with measured levels 
(Inman et al., 1980). Problems in interpretation also arise since levels of immune complexes measured by different methods correlate poorly (Lambert et al., 1978).

Understanding of immune complex mediated pathogenetic mechanisms gained from animal studies partly explains these inconsistencies: thus, immune complexes may circulate for a limited time (Dixon et $a l ., 1958$ ), may be rapidly removed from tissues (Fye $e t$ al., 1977) and other factors such as complement and neutrophils may be required for tissue injury. In addition, measurement of fluid phase immune complexes may be misleading: the methods for immune complex detection are numerous and are mostly indirect, using antigen-nonspecific methods which depend on changes in either physicochemical (e.g. polyethylene glycol precipitation) or biological characteristics (e.g. Clq or rheumatoid factor binding assays) (Theofilopoulos \& Dixon, 1979). Furthermore, recent advances in the understanding of the normal handling of immune complexes suggest that in primates, immune complexes which have activated complement to become coated with $\mathrm{C} 3 \mathrm{~b}$ and $\mathrm{C} 4 \mathrm{~b}$ will bind to the $\mathrm{C} 3 \mathrm{~b}$ receptor (CR1) on erythrocytes. This erythrocyte-mediated carriage of immune complexes to the reticuloendothelial system has been demonstrated in baboons and monkeys (Cornacoff $e t$ al., 1983). However, there is also in vitro evidence that erythrocyte-bound immune complexes are released by the action of factor I (Medof et al., 1982), a physiological inhibitor of the complement system, which cleaves the $\mathrm{C} 3 \mathrm{~b}$ on the immune complex to C3dg. Since C3dg has no affinity for CR1, the immune complex is released from the erythrocyte (Figure 1). This process occurring in whole blood before sample separation (Y.C. $\mathrm{Ng}$, unpublished) results in the detection of immune complexes that are altered in some biological properties including their phlogistic potential, and hence may be pathogenetically irrelevant. Furthermore, any single measurement of immune complexes will be affected by the percentage of complexes in the fluid phase, which in turn depends on factors such as the time elapsed before separation of the sample, changes in complement function, the nature of the immune complex (Horgan et al., 1984) and the density of CR1 on erythrocytes. The number of CR1 sites per erythrocyte is highly variable in the normal population (Ida et al., 1982) and is significantly reduced in systemic lupus erythematosus (Iida et al., 1982; Miyakawa et al., 1981; Walport et al., 1985) and rheumatoid arthritis (Iida et al., 1982).

Evidence linking immune complexes with primary systemic vasculitides is even more tenuous than for the secondary vasculitides. Circulating or deposited immune complexes, cryoglobulinaemia or hypocomplementaemia are the exception rather than the rule. For example, a recent study examined the incidence of these abnormalities in 43 patients with polyarteritis or Wegener's granulomatosis (Ronco et al., 1983). Cryoglobulins were detectable in about $20 \%$ and hypocomplementaemia was not found. Immune complexes were detectable in less than one third of patients using a Raji cell assay but in most patients using a Clq binding assay. Deposits of immunoglobulin or complement in renal arterial walls and glomeruli were scant. These studies suggest that immune complexes may not be the primary pathogenetic mechanism inducing these types of vasculitis.

Host factors which affect deposition of immune complexes and pathogenesis of tissue injury It is likely that the potential pathogenicity of immune complexes will partly depend on the physicochemical and biological properties of the antigen, the antibody and the complex - factors which have been discussed in detail in other reviews (Nydegger \& Lambert, 1980). Briefly, the molecular size of the antigen, the number of antigenic sites recognized by antibody, the affinity and concentration of antibody, and the ratio of antigen to antibody concentrations, influence the characteristics of the immune complex generated. Host factors, such as the state of the reticuloendothelial system, abnormalities of the complement system and local tissue factors (ultrastructure, cellular receptors etc.) are also

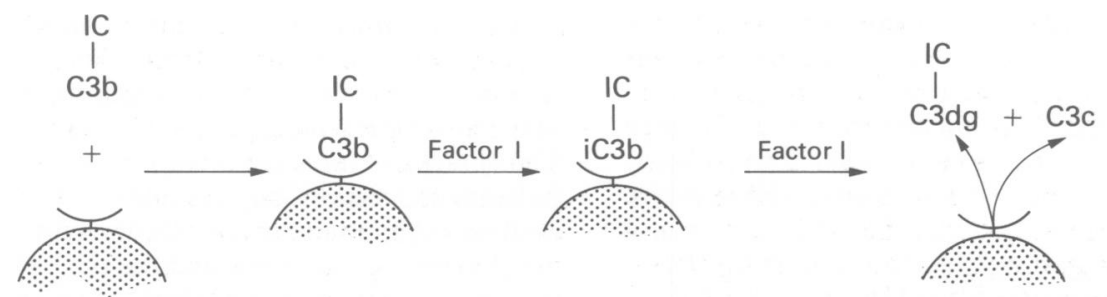

Figure 1 Interactions between opsonized immune complex, CR1 and Factor I. IC = immune complex;

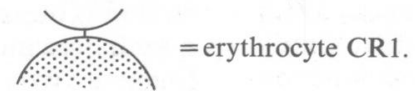


likely to be of major importance in determining the susceptibility of the host and of individual organs to immune complex mediated tissue injury and in dictating the pathological and clinical manifestations.

The effect of abnormalities of the reticuloendothelial system on clearance and thereby, deposition, of immune complexes has been investigated in patients with vasculitis by measuring the rate of removal of heat damaged or antibody-coated red cells by the spleen. Most of the studies have been performed on patients with systemic lupus erythematosus or rheumatoid arthritis. Some investigators have found defective removal of erythrocytes which have correlated with levels of circulating immune complexes or disease activity (Lockwood et al., 1979; Frank et al., 1979; Williams et al., 1979; Hamburger $e t$ al., 1982). An association between immune clearance defects and HLA-B8 DR3 (Lawley et al., 1981) or HLA-DR2 (Kimberley et al., 1983) has also been reported. It has been suggested that these associations could arise from a direct blocking effect of circulating immune complexes on reticuloendothelial $\mathrm{Fc}$ receptor function (Lockwood et al., 1979) or, alternatively, that some patients may have a genetically determined Fc receptor defect that predisposes to immune dysregulation (Lawley et al., 1981; Kimberley et al., 1983). In support of an acquired reticuloendothelial system dysfunction is the demonstration of reversibility with plasma exchange (Lockwood et al., 1979). However, others have failed to demonstrate defective clearance of IgG coated or heat damaged erythrocytes in these diseases (Elkon et al., 1980; Kabbash et al., 1982; Swaak et al., 1984), indeed the value of IgG coated erythrocyte clearance as a measure of reticuloendothelial Fc receptor function has been questioned (Frank et al., 1983) and the mechanisms of clearance of heat damaged erythrocytes are even less clear. Thus, at the present time, data on reticuloendothelial function in patients with vasculitis is conflicting and the situation is far from clear.

Deficiencies of the complement system are associated with an increased incidence of immune complex mediated disease. This association is strongest in patients with inherited defects of the classical pathway, particularly $\mathrm{Cl}$ subcomponents or $\mathrm{C4}$ (Schifferli \& Peters, 1983), but the reasons for this association are not entirely clear. Since $\mathrm{C} 2, \mathrm{C} 4$ and Factor B are encoded within the MHC, it has been suggested that the association results from linkage disequilibrium with other disease susceptibility genes. However, genes for $\mathrm{Clr}, \mathrm{Cls}, \mathrm{Clq}$ and $\mathrm{C} 3$ are not linked to HLA, suggesting that it is loss of complement function that is important: the classical complement pathway is involved in the inhibition of precipitation of antigen-antibody complexes (Schifferli et al., 1982) whereas solubilization of antigen-antibody precipitates is mainly an alternative pathway function
(Czop \& Nussenzweig, 1976). In addition, the ineffective generation of $\mathrm{C} 3 \mathrm{~b}$ and $\mathrm{C} 4 \mathrm{~b}$ on immune complexes may result in inefficient CR1-mediated transport to the reticuloendothelial system. Defects in these functions of complement may favour deposition of highly phlogistic immune complexes in these patients.

Other host factors which may determine the pattern of immune complex deposition include tissue ultrastructure and cell surface receptors. For example (i) glomerular capillaries which are frequently involved in vasculitic processes. receive a high blood flow, are under pressure and have a fenestrated endothelium which may facilitate immune complex trapping. (ii) Cell surface receptors may be altered by, for example, injury which can induce endothelial cells to express Fc receptors and C3 receptors (Ryan et al., 1981; Cines et al., 1982), thereby promoting active binding of immune complexes to these cells. Renal epithelial cells have been found to express CR1 (Fearon, 1984) and both $\mathrm{CR} 1$ and $\mathrm{Fc}$ receptors have been detected in human choroid plexus (Peress et al., 1981; Braathen et al., 1979), although the function of receptors in these sites is unknown.

(c) Antigens responsible for immune complex vasculitis

Identification of the nature of the antigens in immune complexes is potentially of value in determining the precise disease aetiology and in allowing the adminis tration of accurate therapy (Nydegger, 1985).

Animals Spontaneous immune-complex disease occurs in both animals and man as a result of both foreign and autologous antigens. In animals, vasculitic disease may result from viral infection; for example there is strong evidence for the participation of viral antigen-host antibody complexes in the pathogenesis of aleutian disease of mink (Henson \& Gorham, 1973). Animals, particularly NZB/NZW F1 hybrid mice, may develop autoimmune disease with DNA-antiDNA complexes (Cochrane \& Koffler, 1973).

Vasculitis and specific infection in man In man, the best known example of a foreign antigen provoking immune complex mediated vasculitis is that associated with hepatitis B (Gocke et al., 1970; Trepo et al., 1970). The clinical features are often very similar to those of patients with necrotizing vasculitis of the polyarteritis nodosa type; there is no relationship between the development of vasculitis and the type of liver disease present. Circulating hepatitis $B$ surface antigen (HbsAg)-antibody complexes have been demonstrated (Gocke et al., 1970) and deposits of $\mathrm{HbsAg}$, immunoglobulins and complement components found in vascular lesions (Trepo et al., 1974). Hy- 
pocomplementaemia (Duffy et al., 1976) and cryoglobulinaemia (Levo et al., 1977) may accompany the vasculitis and the cryoprecipitate may contain both $\mathrm{HbsAg}$ and antibody, further supporting the concept of immune complex mediated vascular injury. However, despite such strong supportive evidence for a causative role of $\mathrm{Hbs} \mathrm{Ag}$, not all investigators have been able to confirm this (Ewan et al., 1981). Passive trapping of the abundant circulating viral antigen has not been rigorously excluded. Further, in most studies the sexual preferences of the patients were not given and a large number of homosexuals having other concurrent infections was not ruled out.

Vasculitis in man has been associated with a variety of other viral infections including herpes simplex (Phinney et al., 1982), cytomegalovirus infection (Doherty \& Bradfield, 1981) and more recently, human serum parvovirus (Li Loong et al., 1986). Bacterial antigens from several agents including streptococci (Ingelfinger et al., 1977), staphylococci (Boulton-Jones et al., 1974) and meningococci (Davis et al., 1976) have also been implicated. Both antigen and specific antibody have been found in lesions (Nydegger, 1985). In such infections, the immune response of the host may play a major role in determining the pathological manifestations: in subacute bacterial endocarditis complexes were mainly found in patients with disease of longer duration and with marked systemic manifestations (Bayer et al., 1977).

In Kawasaki disease (mucocutaneous lymph node syndrome) there is indirect evidence that an as yet unidentified infective organism may provoke the vasculitic illness; a feverish phase is followed in the third week by thrombocytosis, increased platelet aggregation, serotonin release and circulating immune complexes. The latter may be responsible for the platelet aggregation (Levin et al., 1985). There are many similarities between the manifestations of this disease and serum sickness.

Drugs and vasculitis Several drugs have been associated with the development of vasculitis, including iodine (Rich \& Gregory, 1943), sulphonamides (Rose \& Spender, 1957), penicillin (Waugh, 1952), and, more recently alclofenac (Billings et al., 1974). Vasculitis has also followed vaccination with inactivated influenza virus (Blumberg et al., 1980) and desensitizing injections for atopic respiratory disease (Phanuphak \& Kohler, 1980). However, a major problem with these observations is determining whether a drug was given for early manifestations of the vasculitis or whether it played a truly causative role; similarly, a cause and effect relationship between vaccination, desensitizing injections and vasculitis has not been proven.
Neoplasia and vasculitis Clinical vasculitis syndromes have been associated with neoplasia, including hairy cell leukaemia (Elkon et al., 1979; Goedert et al., 1981), chronic leukaemia (McCombs, 1965), Hodgkin's disease (Sams et al., 1968), multiple myeloma (Williams et al., 1985) and the 'pre-leukaemic' stage of monocyte leukaemia (Leung et al., 1986). The reasons for an association between arteritis and malignant lymphoproliferative diseases are not clear. It has been suggested that infiltration of the reticuloendothelial system by malignant cells may hamper clearance of immune complexes (Elkon et al., 1979), but others favour a common pathogenesis predisposing to the development of both disorders (Goedert et al., 1981).

Autoantigens and vasculitis in man Autoimmune reactions are frequently associated with vasculitis. Immunoglobulins may act as rheumatoid factors and cryoglobulins in diseases such as SLE, rheumatoid arthritis and bacterial endocarditis (Nydegger, 1985; Theofilopoulos \& Dixon, 1979). In addition, the participation of idiotype - anti-idiotype complexes in immune complex mediated disease opens up new possibilities (Kunkel, 1984). In one study of patients with mixed essential cryoglobulinaemia, the IgM monoclonal component reacted with the $\mathrm{F}(\mathrm{ab})_{2}$ fragments of the IgG. The cryoglobulin contained antibodies to $\mathrm{HbsAg}$ which was found to inhibit binding between the cryoglobulin IgM and the $F(a b)_{2}$ of IgG. HbsAg was not inhibitory for cryoglobulins lacking hepatitis antibodies (Geltner et al., 1980), implying that some cryoglobulins contain idiotype anti-idiotype immune complexes.

\section{(d) Summary of the role of immune complexes in the pathogenesis of vasculitis}

Animal models of vasculitis suggest that immune complexes may play a central role in pathogenesis. Several human diseases associated with vasculitis (particularly the secondary vasculitides) are accompanied by striking serological abnormalities which support these concepts. The pathogenesis of the primary vasculitides (e.g. polyarteritis and Wegener's granulomatosis) are less easy to explain in this way since immunological abnormalities, whilst present, are less striking. The association between vasculitis, hepatitis B and some bacterial antigens, suggests that infectious agents could be implicated in the aetiology of vasculitic syndromes. The reasons for the pattern and severity of tissue involvement in each particular disease remain unclear, and the target of immune injury within the vessel wall itself is unknown.

\section{Direct antibody attack}

There is evidence that cell specific autoantibodies may 
contribute to pathogenesis of tissue injury in some vasculitic diseases. Such mechanisms may also be considered as 'in situ' complex formation with antibody binding to autologous antigens, but they will be discussed separately from the previous section, since they raise some interesting points.

In SLE, IgG anti-endothelial antibodies have been demonstrated (Cines et al., 1984) which can fix C3 and release PGI2 from endothelial cells with subsequent adherence of platelets. It has been suggested, but not proven, that $D / D R$ antigens are the target antigen since both B cells and monocytes can adsorb out the activity. Such surface-bound IgG could potentially attract leucocytes to the vessel wall allowing a variety of mediators of tissue injury to participate.

Autoantibodies have also been found in Wegener's granulomatosis (van der Woude et al., 1985; Jones \& Lockwood, unpublished observations) which appear to be directed towards extranuclear components of granulocytes and monocytes. The significance of such antibodies for the pathogenesis of the small vessel vasculitis and the granulomatous reaction found in Wegener's, is unclear at the present time. However, it is interesting that intravascular lysis of leucocytes has been described as an early event in the process of tissue injury (Donald et al., 1976); the lysis was followed by platelet aggregation and fibrin deposition in vessels with intact endothelial cells.

The detection of antibodies to granulocytes and monocytes is intriguing in view of the demonstration, using monoclonal antibodies, of shared antigens between blood monocytes, granulocytes, tissue macrophages and some types of endothelial cells (Hogg et al., 1984; Knowles et al., 1984). Endothelial cells and macrophages were found to share unique non-HLADR antigens not expressed on B lymphocytes or other tissues which may have important implications for lymphocyte-endothelial cell interaction (see below). In other studies, the monoclonal antibody OKM5, showed that antigenically distinct types of endothelial cell were present within one organ, namely the kidney; OKM5 was reactive with renal medullary, but not cortical, small vessel endothelial cells, and was unreactive with glomerular capillary endothelial cells (Knowles et al., 1984). Such observations suggest tissue specificity of the vasculitic process may partly depend on the surface molecules which endothelial cells carry, and that these may vary both between and within organs.

\section{Cellular mechanisms}

The role of particular cell types namely endothelial cells, vascular smooth muscle cells, eosinophils and lymphocytes will be discussed. It is likely that macrophages are also involved, particularly in the granulomatous vasculitic disorders, but information on the nature of their participation is scant. (a) Cellular mechanisms in lymphocyte-predominant vasculitis

Some types of vasculitis are characterized by a perivascular lymphocyte and macrophage infiltrate (Soter \& Austen, 1980) with few, if any, accompanying neutrophils which are so characteristic of the immune complex-induced serum sickness of vasculitis. The lymphocyte-predominant type of vasculitis is particularly associated with cutaneous vasculitides (Soter \& Austen, 1980) but may be observed in human systemic vasculitis (McCluskey \& Fienberg, 1983) and it has been suggested by some investigators that nonimmune complex mediated mechanisms of injury may be involved (Moyer \& Reinisch, 1984). Thus the role of endothelial and smooth muscle cells in promoting the lymphocyte influx is under investigation.

Endothelial cells have the potential to play an active role in the induction of vasculitis since not only may they share surface determinants with various haemopoietic cell lines (see above) (Ryan et al., 1981; Hirschberg et al., 1979), but they are also capable of behaving as antigen presenting cells (Hirschberg et al., 1980). In one study BALB/c splenic lymphocytes were activated by co-culturing in vitro and in vivo with an endothelial mouse cell line (ME-2 cells); the lymphocytes underwent proliferation and were then injected intravenously into syngeneic mice who develope $\$$ vasculitis in the lungs, brain and other organs. It was suggested that endothelial cell antigens (cross-reactive between ME-2 cells and BALB/c endothelial cells) were able to sensitize the splenic lymphocytes which, following injection into the host, were able to by-pass suppressor mechanisms and recruit host cells to amplify vascular injury (Hart et al., 1983).

It has also been proposed that vascular smooth muscle cells (VSMC) may play an active role in recruiting lymphocytes (Moyer \& Reinisch, 1984). In vitro studies of VSMCs and splenocytes from the MRL/1pr mouse, which is particularly prone to develop arteritis, showed that the VSMCs were able to stimulate a mononuclear inflammatory cell phlogistic response, culminating in VSMC autodestruction. The VSMCs from these autoimmune mice spontaneously express Ia (which could promote T-cell sensitization to 'self' antigens) and released an interleukin-I-like factor (which could encourage a lymphoid influx into the vascular site).

Preliminary studies in humans suggest lymphocytes may play a role in certain types of vasculitis. Thus, increased lymphocyte mediated cytotoxicity to ${ }^{111}$ indium-labelled human endothelial cells was observed in 7 patients with giant cell arteritis and Takayasu's disease, whilst serum mediated cytotoxicity (e.g. mediated by oxidized lipoproteins) was increased in 7 patients with systemic necrotizing vasculitis (Scott et al., 1984). 


\section{(b) The role of eosinophils in vasculitis}

The Churg-Strauss syndrome is characterized by hypereosinophilia and a granulomatous vasculitis (Churg \& Strauss, 1952). Activated and degranulated eosinophils have been seen migrating towards the granulomatous lesions which have been found to contain large amounts of eosinophil cationic protein and eosinophil protein-X (which are toxic to many cells and tissues) (Tai et al., 1984). Raised IgE levels are found in some patients with the syndrome which may trigger eosinophils to take part in cytotoxic reactions (Conn et al., 1976) via their recently demonstrated IgE receptors (Capron et al., 1981). Thus it is possible that eosinophils play a central role in the pathogenesis of this granulomatous vasculitis and the severity of the disease may be partly related to the extent of eosinophil degranulation in tissues.

Wegener's granulomatosis is also a granulomatous vasculitis in which elevated IgE levels have been reported (Conn et al., 1976) but a role for eosinophils, if any, in this disease has not yet been substantiated.

\section{Non-immuno-pathogenetic mechanisms.}

Non-immunological mechanisms may cause vasculitis, including necrotizing arteritis. Encephalomyocarditis of mice is probably caused by direct infection of vascular elements by virus, and viral particles have been demonstrated in and around the

\section{References}

BAART DE LA FAILLE-KUYPER, E.H., KATER, L., KOOIKER, C.J. \& MEES, E.J.D. (1973). IgA-deposits in cutaneous blood-vessel walls and mesangium in Henoch-Schonlein syndrome. Lancet, i, 479.

BAYER, A.S., THEOFILOPOULOS, A.N., EISENBERG, R., FRIEDMAN, S.G. \& GUZE, L.B. (1977). Thrombotic thrombocytopenia purpura-like syndrome associated with infective endocarditis. A possible immune complex disorder. Journal of the American Medical Association, 238, 408.

BILLINGS, S., BURRY, H.C., EMSLIE, F.S. \& KERR, G.D. (1974). Vasculitis with alclofenac therapy. British Medical Journal, 4, 263.

BLUMBERG, S., BIENFANG, D. \& KANTROWITZ, F.G. (1980). A possible association between influenza vaccination and small-vessel vasculitis. Archives of Internal Medicine, 140, 847.

BOULTON-JONES, J.M., SISSONS, J.G.P., EVANS, D.J. \& PETERS, D.K. (1974). Renal lesions of subacute infective endocarditis. British Medical Journal, 2, 11.

BRAATHEN, L.R., FORRE, C.T., HUSBY, G. \& WILLIAMS, R.C. JR. (1979). Evidence for Fc IgG receptors and complement factor $\mathrm{C} 3 \mathrm{~b}$ receptors in human choroid plexus. Clinical Immunology and Immunopathology, 14, 284.

CAPRON, M., CAPRON, A., DESSAINT, J.-P., TORPIER, G., blood vessels (Sergent, 1980). Turkeys injected with mycoplasma gallisepticum develop cerebral arteritis which seems to be mediated by mycoplasma toxins (Thomas et al., 1966). Necrotizing arteritis may occur in rats with spontaneous hypertension and the vascular lesions may contain immunoglobulin (Ohta et al., 1959).

\section{Conclusions}

The aetiology and pathogenesis of vasculitis and of the primary systemic vasculitides in particular, remain largely speculative - progress has been hampered by the considerable clinical and pathological overlap between many of the syndromes. The animal models of serum sickness and the Arthus reaction have been helpful in understanding certain aspects of the pathogenesis of these disorders but many gaps and inconsistencies remain. It is likely that both humoral and cellular mechanisms mediate tissue injury but specificity must develop at some point to allow a patient with say, polyarteritis nodosa to be differentiated from one with Wegener's granulomatosis.

\section{Acknowledgements}

COSS and YCN acknowledge the support of the Medical Research Council, the critical comments of Professor D.K. Peters and the secretarial assistance of Miss Sue Goodwin.

GUNNAR, S., JOHANSSON, O. \& PRIN, L. (1981). Fc receptors for IgE on human and rat eosinophils. Journal of Immunology, 126, 2087.

CHUMBLEY, L.C., HARRISON, E.G., DEREMEE, R.A. (1977). Allergic granulomatosis and angiitis (Churg-Strauss syndrome). Report and an analysis of 30 cases. Mayo Clinic Proceedings, 52, 477.

CHURG, J. \& STRAUSS, L. (1952). Allergic granulomatosis, allergic angiitis and periarteritis nodosa. American Journal of Pathology, 27, 277.

CINES, D.B., LYSS, A.P., BINA, M., CORKEY, R., KEFALIDES, N.A. \& FRIEDMAN, H.M. (1982). Fc and C3 receptors induced by herpes simplex virus on cultured human endothelial cells. Journal of Clinical Investigation, 69, 123.

CINES, D.B., LYSS, A.P., REEBER, M. BINA, M., DEHORATIUS, R.J. (1984). Presence of complement-fixing anti-endothelium cell antibodies in systemic lupus erythematosus. Journal of Clinical Investigation, 73, 611.

CLARK, E. \& KAPLAN, B.J. (1937). Endocardial, arterial and other mesenchymal alterations associated with serum sickness disease in man. Archives of Pathology, 24, 458.

COCHRANE, C.G., WEIGLE, W.O. \& DIXON, F.J. (1959). The role of polymorphonuclear leukocytes in the initiation and cessation of the Arthus reaction. Journal of Experimental Medicine, 110, 481. 
COCHRANE, C.G. (1985). In The Inflammatory Process, Zweifach, B.W., Grant, L., McCluskey, R.T. (eds). p. 613. Academic Press: New York.

COCHRANE, C.G. \& KOFFLER, D. (1973). Immune complex disease in experimental animals and man. Advances in Immunology, 16, 185.

COHEN, R.D., CONN, D.L. \& ILSTRUP, D.M. (1980). Clinical features, prognosis and response to treatment in polyarteritis. Mayo Clinic Proceedings, 55, 146.

CONN, D.L., McDUFFIE, F.C. \& DYCK, P.J. (1972). Immunopathologic study of sural nerves in rheumatoid arthritis. Arthritis and Rheumatism, 15, 135.

CONN, L.C., MCDUFFIE, F.C., HOLLEY, K.E. \& SCHROETER, A.L. (1976). Immunologic mechanisms in systemic vasculitis. Mayo Clinic Proceedings, 51, 511.

CORNACOFF, J.B., HERBERT, L.A., SMERD, W.L., VANAMAN, M.E., BIRMINGHAM, D.J. \& WAXMAN, F.J. (1983). Primate erythrocyte-immune complex-clearing mechanism. Journal of Clinical Investigation, 71, 236.

COUNAHAN, R., WINTERBORN, M.H., WHITE, R.H.R., HEATON, J.M., MEADOW, S.R., BLUETT, N.H. \& SWETSCHIN, H. (1977). Prognosis of Henoch-Schonlein nephritis in children. British Medical Journal, 2, 11.

CUPPS, T.R. \& FAUCI, A.S. (1982). The vasculitic syndromes. Advances in Internal Medicine, 27, 315.

CZOP, J. \& NUSSENZWEIG, V. (1976). Studies on the mechanism of solubilisation of immune precipitates by serum. Journal of Experimental Medicine, 143, 615.

DAVIS, J.A.S., PETERS, N., MOHAMMED, I., MAJOR, G.A.C. \& HOLBOROW, E.J. (1976). Circulating immune complexes in a patient with meningococcal disease. British Medical Journal, 1, 1445.

DIXON, F.J., VAZQUEZ, J.J., WEIGLE, W.O. \& COCHRANE, C.G. (1958). Pathogenesis of serum sickness. Archives of Pathology, 65, 18.

DOHERTY, M. \& BRADFIELD, J.W.B. (1981). Polyarteritis nodosa associated with acute cytomegalovirus infection. Annals of Rheumatic Diseases, 40, 419.

DONALD, K.J., EDWARDS, R.L. \& McEVOY, J.D.S. (1976). An ultrastructural study of the pathogenesis of tissue injury in limited Wegener's granulomatosis. Pathology, 8, 161.

DUFFY, J., LIDSKY, M.D., SHARP, J.T., DAVIS, J.S., PERSON, D.A., HOLLINGER, F.B. \& MIN, K.W. (1976). Polyarthritis, polyarteritis and hepatitis B. Medicine (Baltimore), 55, 19-37.

ELKON, K.B., HUGHES, G.R.V., CATOVSKY, D., CLAUVEL, J.P., DUMONT, J., SELIGMAN, M. \& TANNENBAUM, H. (1979). Hairy-cell leukaemia with polyarteritis nodosa. Lancet, ii, 280.

ELKON, K.B., SEWELL, J.R., RAYAN, P.F.J. \& HUGHES, G.R.V. (1980). Splenic function in non-renal systemic lupus erythematosus. American Journal of Medicine, 69, 80.

EWAN, P.W., WATERSON, A.P. \& PETERS, D.K. (1981). An 8 year survey of hepatitis $B$ antigen in a hospital population. In Systemic Effects of HBsAg Immune Complexes, Bartol, E., Chiandussi, L. \& Sherlock, S. (eds). p. 1. Piccin Medical Books: Padova.

FAUCI, A.S., HAYNES, B.F. \& KATZ, P. (1978). The spectrum of vasculitis, clinical, pathologic, immunologic and therapeutic considerations. Annals of Internal Medicine, 89,660 .

FAUCI, A.S., HAYNES, B.F., KATZ, P. \& WOLFF, S.M. (1983). Wegener's granulomatosis: prospective clinical and therapeutic experience with 85 patients for 21 years. Annals of Internal Medicine, 98, 76.

FEARON, D.T. (1984). Cellular receptors for fragments of the third component of complement. Immunology Today, 5 , 105.

FLIGIEL, S.E.G., WARO, P.A., JOHNSON, K.J. \& TILL, G.O (1984). Evidence for a role of hydroxyl radical in immunecomplex-induced vasculitis. American Journal of Pathology, 115, 375.

FRANK, M.M., HAMBURGER, M.L., LAWLEY, T.J., KIMBERLEY, R.P. \& PLOTZ, R.H. (1979). Defective reticuloendothelial system Fc-receptor function in systemic lupus erythematosus. New England Journal of Medicine, 300, 518.

FRANK, M.M., LAWLEY, T.J., HAMBURGER, M.I. \& BROWN, J. (1983). Immunoglobulin G Fc receptor-mediated clearance in autoimmune diseases. Annals of Internal Medicine, 98, 206.

FRANKLIN, E.C. (1980). The role of cryoglobulins and immune complexes in vasculitis. Journal of Allergy and Clinical Immunology, 66, 269.

FYE K.H., BECKER, M.J., THEOFILOPOULOS, A.N., MOUTSOPOULOS, H., FELDMAN, J.-L., \& TALAL, N. (1977). Immune complexes in hepatitis $B$ antigen-associated periarteritis nodosum. Detection by antibody-dependent cell-mediated cytotoxicity and the Raji cell assay. American Journal of Medicine, 62, 783.

GELTNER, D., FRANKLIN, E.C. \& FRANGISNE, B. (1980). Antiidiotypic activity in the IgM fractions of mixed cryoglobulins. Journal of Immunology, 125, 1530.

GERMUTH, F.G. (1953). A comparative histologic and immunologic study in rabbits of induced hypersensitivityô of the serum sickness type. Journal of Experimenta Medicine, 97, 257.

GOCKE, D.J., HSU, K., MORGAN, C., BOMBARDIERI, S., LOCKSHIN, M. \& CHRISTIAN, C.L. (1970). Association between polyarteritis and Australia antigen. Lancet, ii, 1149.

GOEDERT, J.J., NEEFE, J.R., SMITH, F.S., STAHL, N.I., JAFFE, E.S. \& FAUCI, A.S. (1981). Polyarteritis nodosa, hairy cell leukaemia and splenosis. American Journal of Medicine, 71, 323.

GOREVIC, P.D., KASSAB, H.J., LEVO, Y., KOHN, R., MELTZER, M., PROSE, P. \& FRANKLIN, E.C. (1980). Mixed essential cryoglobulinaemia: clinical aspects and long-term follow-up of 40 patients. American Journal of Medicine, 69, 287.

HAMBURGER, M.I., LAWLEY, T.J., KIMBERLY, R.P., PLOTZ, P.H. \& FRANK, M.M. (1982). A serial study of splenic reticuloendothelial system $\mathrm{Fc}$ receptor functional activity in systemic lupus erythematosus. Arthritis and Rheumatism, 25, 48.

HART, M.N., SADEWASSER, K.L., CANCILLA, P.A., DEBAULT, L.E. (1983). Experimental autoimmune type of vasculitis resulting from activation of mouse lymphocytes to cultured endothelium. Laboratory Investigation, 48, 419.

HENSON, J.B. \& GORHAM, J.R. (1973). Animal model of human disease: persistent viral infections, immunologically mediated glomerulonephritis and arteritis, dysgammopathies. American Journal of Pathology, 71, 345.

HENSON, P.M. (1982). Antibody and immune-complexmediated allergic and inflammatory reactions. In Clinical Aspects of Immunology, Lachmann, P.J., Peters, D.K. (eds). p. 687, 4th Edition. Blackwell Scientific Publications: Oxford. 
HIRSCHBERG, H., MOEN, T. \& THORSBY, T. (1979). Specific destruction of human endothelial cell monolayers by antiDRW antisera. Transplantation, 28, 116.

HIRSCHBERG, H., BERGH, O.J. \& THORSBY, E. (1980). Antigen presenting properties of human vascular endothelial cells. Journal of Experimental Medicine, 152, 249 S.

HOGG, N., MAcDONALD, S., SLUSARENKO, M. \& BEVERLEY, P.C.L. (1984). Monoclonal antibodies specific for human monocytes. Granulocytes and endothelium. Immunology, 53, 753.

HORGAN, C., BURGE, J., CRAWFORD, L. \& TAYLOR, R.P. (1984). The kinetics of 3H-DSDNA/anti-DNA immune complex formation. Binding by red cells and release into serum: Effect of DNA molecular weight and conditions of antibody excess. Journal of Immunology, 133, 2079.

IIDA, K., MORNAGHI, R. \& NUSSENZWEIG, V. (1982). CR1 deficiency in red cells from patients with systemic lupus erythematosus. Journal of Experimental Medicine, 155, 1427.

INGELFINGER, J.R., MCCLUSKEY, R.T., SCHNEEBERGER, E.E. \& GRUPE, W.E. (1977). Necrotizing arteritis in acute poststreptococcal glomerulonephritis. Pediatrics, 91, 228.

INMAN, R.D., FUNG, J.K.K., PUSSELL, B.A., RYAN, P.J. \& HUGHES, G.R.V. (1980). The Clq binding assay in systemic lupus erythematosus. Discordance with disease activity. Arthritis and Rheumatism, 23, 1282.

IZUI, S., LAMBERT, P.-H. \& MIESCHER, A. (1976). In vitro demonstration of a particular affinity of glomerular basement membrane and collagen for DNA. A possible basis for a local formation of DNA-anti-DNA complexes in systemic lupus erythematosus. Journal of Experimental Medicine, 144, 428.

KABBASH, L., BRANDWEIN, S., ESDAILE, J., DANOFF, D., FUKS, A. \& SHUSTER, J. (1982). Reticuloendothelial system Fc receptor function in systemic lupus erythematosus. Journal of Rheumatology, 9, 374.

KIMBERLEY, R.P., GIBOVSKY, A., SALMON, J.E. \& FOTINO, M. (1983). Impaired Fc-mediated mononuclear phagocyte system clearance in HLA-DR2 and MTI-positive healthy young adults. Journal of Experimental Medicine, 157, 1698.

KNOWLES, D.M., TOLIDJIAN, B., MARBOE, C., D'AGATI, V., GRIMES, M. \& CHESS, L. (1984). Monoclonal anti-human monocyte antibodies OKM1 and OKM5 possess distinctive tissue distributions including differential reactivity with vascular endothelium. Journal of Immunology, 132, 2170.

KUNKEL, H.G. (1984). In Idiotypy in Biology and Medicine, 1st Edition, Kohler, H., Urbain, H. \& Cazenave, P.-A. (eds). p. 429. Academic Press: London.

LAMBERT, P.H., DIXON, F.J., ZUBLER, R.H. AND MEMBERS OF THE STUDY GROUP (1978). WHO collaborative study for the evaluation of eighteen methods for detecting immune complexes in serum. Journal of Clinical and Laboratory Immunology, $1,1$.

LAWLEY, T.J., HALL, R.P., FAUCI, A.S., KATZ, S.I., HAMBURGER, M.L. \& FRANK, M.M. (1981). Defective Fc receptor functions associated with the HLA-B8 DRW3 haplotype. New England Journal of Medicine, 304, 185.

LAWLEY, T.J., BIELORY, L., GASCON, P., YANCEY, K.B., YOUNG, N. \& FRANK, M.M. (1984). A prospective clinical and immunologic analysis of patients with serum sickness. New England Journal of Medicine, 311, 1407.

LEUNG, A.T.C., McLAY, A. \& BOULTON-JONES, J.M. (1986). Polyarteritis nodosa and monocytic leukaemia. Post- graduate Medical Journal, 62, 35.

LEVIN, M., HOLLAND, P.C., NOKES, T.J.C., NOVELLI, V., MOLA, M., LEVINSKY, R.J., DILLON, M.J. \& BARRATT, T.M. (1985). Platelet immune complex interaction in pathogenesis of Kawasaki disease and childhood polyarteritis. British Medical Journal, 290, 1456.

LEVO, Y., GOREVIC, P.D., KASSAT, H.J., ZUCKER-FRANKLIN, D. \& FRANKLIN, E.C. (1977). Association between hepatitis B virus and essential mixed cryoglobulinaemia. New England Journal of Medicine, 298, 126.

LOCKWOOD, C.M., WORLLEDGE, S., NICHOLAS, A., COTTON, C. \& PETERS, D.K. (1979). Reversal of impaired splenic function in patients with nephritis or vasculitis (or both) by plasma exchange. New England Journal of Medicine, 300, 524.

LI LOONG, T.C., COYLE, P.V., ANDERSON, M.J., ALLEN, G.E. \& CONNOLLY, J.H. (1986). Human serum parvovirus associated vasculitis. Postgraduate Medical Journal, 62, 493.

MATSUO, S., CALDWELl, P.R.B., BRENTJENS, J.R. \& ANDREAS, G. (1985). In vivo interaction of antibodies with cell surface antigens. A mechanism responsible for in situ formation of immune deposits in the zona pellucida of rabbit oocytes. Journal of Clinical Investigation, 75, 1369.

MCCLUSKEY, R.T. \& FIENBERG, R. (1983). Vasculitis in primary vasculitides, granulomatoses, and connective tissue diseases. Human Pathology, 14, 305.

McCOMBS, R.P. (1985). Systemic "allergic" vasculitis. Clinical and pathological relationships. Journal of the American Medical Association, 194, 1059.

MEDOF, M.E., PRINCE, G.M. \& MOLD, C. (1982). Release of soluble immune complexes from immune adherence receptors on human red blood cells is mediated by $\mathrm{C} 3 \mathrm{~b}$ inactivator independent of $\mathrm{B} 1 \mathrm{H}$ and accompanied by generation of C3c. Proceedings of the National Academy of Sciences of the USA, 79, 5047.

MIYAKAWA, Y., YAMEDA, A. \& KOSAKA, K. (1981). Defective immune adherence (C3b) receptor on red cells from patients with systemic lupus erythematosus. Lancet, ii, 493.

MOYER, C.F. \& REINISCH, C.L. (1984). The role of vascular smooth muscle cells in experimental autoimmune vasculitis. I. The initiation of delayed type hypersensitivity angiitis. American Journal of Pathology, 117, 380.

NYDEGGER, U.E. \& LAMBERG, P.H. (1980). The role of immune complexes in the pathogenesis of necrotizing vasculitides. Clinics in Rheumatic Diseases, 6, 255.

NYDEGGER, U.E. (1985). A place for soluble immune complexes in clinical immunology. Immunology Today, 6, 80.

OHTA, G., COHEN, S., SINGER, E.J., ROSENFIELD, R. \& STRAUSS, L. (1959). Demonstration of gamma globulin in vascular lesions of experimental necrotizing arteritis in the rat. Proceedings of the Society for Experimental Biology and Medicine, 102, 187.

PERESS, N.S., ROXBURGH, V.A. \& GELFAND, M.C. (1981). Binding sites for immune components in human choroid plexus. Arthritis and Rheumatism, 24, 520.

PHANUPHAK, P. \& KOHLER, P.F. (1980). Onset of polyarteritis nodosa during allergic hyposensitization treatment. American Journal of Medicine, 68, 479.

PHINNEY, P.R., FLIGIEL, S., BRYSON, Y.J. \& PORTER, D.D. (1982). Necrotizing vasculitis in a case of disseminated neonatal herpes simplex. Archives of Pathology and 
Laboratory Medicine, 106, 64.

PINCHING, A.J., LOCKWOOD, C.M., PUSSELL, B.A., REES, A.J., SWENY, P., EVANS, D.J. \& BOWLEY, N. (1983). Wegener's granulomatosis: observations on 18 patients with severe renal disease. Quarterly Journal of Medicine, 52, 435.

PUSSELL, B.A., LOCKWOOD, C.M., SCOTT, D.M., PINCHING, A.J. \& PETERS, D.K. (1978). Value of immune-complex assays in diagnosis and management. Lancet, ii, 359.

RAPOPORT, R.J., KOZIN, F., MACKEL, S.E. \& JORDON, R.E. (1980). Cutaneous vascular immunofluorescence in rheumatoid arthritis: correlation with circulating immune complexes and vasculitis. American Journal of Medicine, 68, 325.

RICH, A.R. \& GREGORY, J.E. (1943). The experimental demonstration that periarteritis nodosa is a manifestation of hypersensitivity. Bulletin of the Johns Hopkins Hospital, $72,65$.

RONCO, P., VERROUST, P., MIGNON, F., KOURILSKY, O., VANHILLE, P., MEYRIER, A., MERY, J.P. \& MORELMAROGER, L. (1983). Immunopathological studies of polyarteritis nodosa and Wegener's granulomatosis: A report of 43 patients and 51 renal biopsies. Quarterly Journal of Medicine, 52, 212.

ROSE, G.A. \& SPENCER, H. (1957). Polyarteritis nodosa. Quarterly Journal of Medicine, 26, 43.

ROTHBERGER, H., ZIMMERMAN, T.S., SPIEGELBERG, H.L. \& VAUGHAN, J.H. (1977). Leucocyte procoagulant activity. Enhancement of production in vitro by IgG and antigen-antibody complexes. Journal of Clinical Investigation, 59, 549.

RYAN, U.S., SCHULTZ, D.R. \& RYAN, J.W. (1981). Fc and $\mathrm{C} 3 \mathrm{~b}$ receptors on pulmonary endothelial cells: induction by injury. Science, $214,557$.

SAMS, W.M., HARVILLE, D.D. \& WINKELMAN, R.K. (1968). Necrotising vasculitis associated with lethal reticuloendothelial diseases. British Journal of Dermatology, 80, 555.

SAVAGE, C.O.S., WINEARLS, C.G., EVANS, D.J., REES, A.J. \& LOCKWOOD, C.M. (1985). Microscopic polyarteritis: presentation, pathology and prognosis. Quarterly Journal of Medicine, 56, 467.

SCHIFFERLI, J.A., WOO, P. \& PETERS, D.K. (1982). Complement-mediated inhibition of immune precipitation. I. Role of classical and alternative pathways. Clinical and Experimental Immunology, 47, 555.

SCHIFFERLI, J.A. \& PETERS, D.K. (1983). Complement. The immune complex lattice and the pathophysiology of complement-deficiency syndromes. Lancet, ii, 957.

SCOTT, D.G.I., BACON, P.A., ELLIOTT, P.J., TRIBE, C.R. \& WALLINGTON, T.B. (1982). Systemic vasculitis in a district general hospital 1972-1980: Clinical and laboratory features. Classification and prognosis of 80 cases. Quarterly Journal of Medicine, 51292.

SCOTT, D.G.I., BLAKE, D.R., BLANN, A., SALMON, M., BRAILSFORD, S., WINYARD, P. \& BACON, P.A. (1984). The role of lymphocytes and serum factors in vasculitic diseases. (Abst). Annals of Rheumatic Disease, 43, 116.

SERGENT, J.A. (1980). Vasculitides associated with viral infections. Clinics in Rheumatic Diseases, 6, 339.

SERRA, A., CAMERON, J.S., TURNER, D.R., HARTLEY, B., OGG, C.S., NEILD, G.H., WILLIAMS, D.G. \& TAUBE, D.B.
(1984). Vasculitis affecting the kidney: presentation, histopathology and long-term outcome. Quarterly Journal of Medicine, 53, 181.

SOTER, N.A. \& AUSTEN, K.F. (1980). Pathogenetic mechanisms in the necrotizing vasculitides. Clinics in Rheumatic Diseases, 6, 233.

SWAAK, A.J.G., vAN DER KORST, J.K., HOEFNAGEL, C.A., BOOM, F.A. \& MARCUSE, H.R. (1984). The clearance of heat-damaged erythrocytes by the reticulo-endothelial system in systemic lupus erythematosus and rheumatoid arthritis. Rheumatology International, 4, 177.

TAI, P.-C., HOLT, M.E., DENNY, P., GIBBS, A.R., WILLIAMS, B.D. \& SPRY, C.J.F. (1984). Deposition of eosinophil cationic protein in granulomas in allergic granulomatosis and vasculitis: The Churg-Strauss syndrome. British Medical Journal, 289, 400.

TAN, E.M. \& KUNKEL, J.G. (1966). An immunofluorescent study of the skin lesions in systemic lupus erythematosus. Arthritis and Rheumatism, 9, 37.

THEOFILOPOULOS, A. \& DIXON, F.J. (1979). The biology and detection of immune complexes. Advances in Immunology, 28, 89.

THOMAS, L., DAVIDSON, M. MCCLUSKEY, R.T. (1966). Studies of PPLO infection. I. The production of cerebral polyarteritis by mycoplasma gallisepticum in turkeys: the neurotoxic property of the mycoplasma. Journal of Experimental Medicine, 123, 897.

TREPO, C.G. \& THIVOLET, J. (1970). Hepatitis associated antigen and periarteritis nodosa (PAN). Vox Sanguinis, 19, 410.

TREPO, C.G., ZUCKERMAN, A.J., BIRD, R.C. \& PRINCE, A.M. (1974). The role of circulating hepatitis B antigen/antibody immune complexes in the pathogenesis of vascular and hepatic manifestations in polyarteritis nodosa. Journal of Clinical Pathology, 27, 863.

VAN DER WOUDE, F.J., RASMUSSEN, N., LOBATTO, S., WIIK, A., PERMIN, H., VAN ES, L.A. \& VAN DER GIESSEN, M. (1985). Autoantibodies against neutrophils and monocytes: tool for diagnosis and marker of disease activity in Wegener's granulomatosis. Lancet, i, 425.

WALPORT, M.J., ROSS, G.D., MACKWORTH-YOUNG, C., WATSON, J., HOGG, N. \& LACHMANN, P.J. (1985). Family studies of erythrocyte complement receptor Type I levels: reduced levels in patients with SLE are acquired, not inherited. Clinical and Experimental Immunology, 59, 547.

WAUGH, D. (1952). Myocarditis, arteritis and focal hepatic, splenic and renal granulomas apparently due to penicillin sensitivity. American Journal of Pathology, 28, 437.

WILLIAMS, A.J., NEWLAND, A.C. \& MARCH, F.P. (1985). Acute renal failure with polyarteritis nodosa and multiple myeloma. Postgraduate Medical Journal, 62, 445

WILLIAMS, B.D., PUSSELL, B.A., LOCKWOOD, C.M. \& COTTON, C. (1979). Defective reticuloendothelial system function in rheumatoid arthritis. Lancet, i, 1311.

ZUBLER, R.H., BYDEGGER, U., PERRIN, L.H., MCCORMICK, J., LAMBERT, P.H. \& MIESCHER, P.A. (1976). Circulating and intraarticular immune complexes in patients with rheumatoid arthritis. Correlation of ${ }^{125} \mathrm{I}-\mathrm{Clq}$ binding activity with clinical and biological features of the diseases. Journal of Clinical Investigation, 57, 1308. 